\title{
Selecting scenarios to assess exposure of surface waters to veterinary medicines in Europe
}

\author{
Manuel K. Schneider ${ }^{1}$, Christian Stamm ${ }^{1}$ and Kathrin Fenner ${ }^{1,2}$ \\ ${ }^{1}$ Eawag, Swiss Federal Institute of Aquatic Science and Technology, 8600 Dübendorf, Switzerland; \\ ${ }^{2}$ Institute of Biogeochemistry and Pollutant Dynamics, ETH Zurich, 8092 Zurich, Switzerland \\ * corresponding author: manuel.schneider@eawag.ch; Ph: +41 4482351 18; Fax: +41 448235471
}

\section{Contents:}

SI-1: Flow chart of the scenario selection procedure $\quad$ S2

SI-2: Disaggregation of census data on manure loads $\quad$ S3

Table S1. Classes and P excretion rates used in calculations of P loads.

Table S2. Land use types aggregated from classes of Corine landcover database, Swiss area statistics and Pelcom map

SI-3: Sources, transformations and interpretation of environmental variable data

Table S3. Variables used for the cluster analysis and the subsequent selection of scenarios for environmental risk assessment of veterinary pharmaceuticals.

\section{SI-4: Robustness of partitioning}

Table S4. Similarity between partitions obtained in cluster analyses with different preparatory steps.

Figure S1, a-f. Partitions obtained after different preparatory steps varying number and type of variables, algorithm and the number of clusters

\section{SI-5: Detailed results of PCA}

Table S5. Results of principal component analysis on environmental variables.

Table S6. Median variable values for scenarios selected from the clustering of the first seven principal components of environmental variables.

Table S7. Median variable values for existing scenarios of Focus and VetCalc.

Table S8. Distance values D between existing and selected scenarios. 


\section{SI-1: Flow chart of the scenario selection procedure}

1. Development of a matrix of factors affecting the contamination potential of surface waters (SW) by veterinary medicinal products (VMP).

2. Transformation of input factors to similar resolution and projection (see SI-4 for details).

3. Clustering of the first seven principal components of environmental factors.

4. Calculation of tendency scores $\mathrm{T}$ (Fig. 1) and scores R using median values of mobility, transport and load factors.

5. Selection of scenarios with R sores in the top $30 \%$ and a size in the top $80 \%$ (Fig. 2 and Table 2).
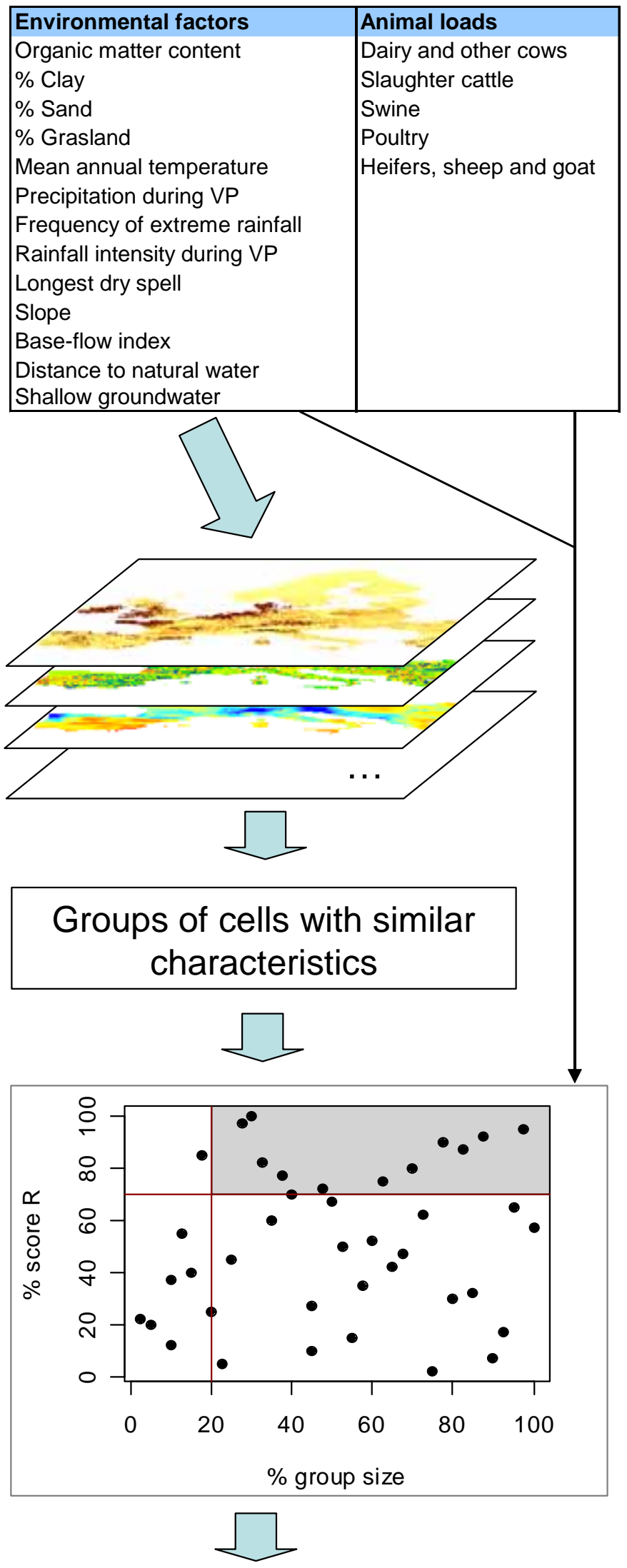

\section{Selected scenarios}




\section{SI-2: Disaggregation of census data on manure loads}

The basic idea behind disaggregation was to distribute manure loads from animals in a particular region onto raster cells with a particular agricultural land use using information on manure management and grazing. Phosphorus (P) excretion was used as proxy for manure loads because it is not influenced by dry matter content of the manure.

In detail, census data obtained from Eurostat and national statistics for the years 2000-2003 were averaged, aggregated into nine animal classes (Table S1) and multiplied with $\mathrm{P}$ excretion rates $E_{P}$ (Table S1). Because Eurostat only provides data for one poultry class, $E_{P}$ for poultry was calculated based on estimated proportions of laying hens and broilers in each country (Harald Menzi, written comm.). In order to account for differences in productivity, $E_{P}$ for dairy cows was adjusted for milk yield $M Y$ obtained at the regional level from the Farm Accountancy Data Network using the regression (1):

$$
E_{P}=39 \mathrm{~kg} \mathrm{P}_{2} O_{5} \begin{cases}+0.2 / 100 \mathrm{kgMY} & \text { if }>6000 \mathrm{kgMY} \\ -0.39 / 100 \mathrm{kgMY} & \text { if }<6000 \mathrm{kgMY}\end{cases}
$$

Country-wise data on the percentage of liquid or solid manure per animal class (2), the utilization of this manure on arable or grassland (2) as well as estimates on housing (3) were used to calculate annual average P loads on arable land and grassland. P loads were then aggregated into the 5 manure classes.

This data, still at the level of the administrative units for which the census data was obtained (Nuts2 regions), was attributed to four land use classes (arable, grass, mixed and marginal land). The four land use classes were reclassified from remote sensing maps of land cover. To cover a larger part of Europe, the Corine 2000 land cover map (European Environment Agency, Copenhagen) was combined with the Swiss land use statistics (Federal Statistical Office, Berne) and the Pelcom map (Winand Staring Centre for Integrated Land, Soil and Water Research, Wageningen) for Norway (Table S2).

Manure of all animal categories was attributed to arable, grass and mixed land, whereas to marginal land only the loads from sheep, goats and heifers during grazing were attributed. These three animal classes were grouped together because all spend significant time grazing marginal grasslands and are primarily treated with parasiticides.

Mixed lands are characterized by a variation of different agricultural and/or non-agricultural land uses at smaller scales than the mapping unit. In order to calculate loads on mixed land, proportions of arable and grassland in mixed land had to be estimated. This was done by comparing for each administrative unit the coverage of the four mapped land use classes with data on agricultural land use from agricultural census. If the land use map indicated a smaller share of arable land in a region than the agricultural census, it was assumed that a higher proportion of mixed land was arable. One has to be aware that all these estimations 
are only approximate and that there may be important deviations between real land use and a map at the European scale (4).

Further correction was needed because information on manure management was only available at the country level. Since livestock and land use distributions may strongly vary within countries, estimates of manure management may not be appropriate for certain regions where land use is very different from the rest of the country. It was found that, for some regions, estimated loads per land use area were unrealistically high. This is especially the case where there is a large discrepancy between manure spread estimate and real land use, e.g. a large proportion of solid manure is used on arable land in a country, but the proportion of arable land in a particular region is very small. We therefore corrected the proportion of manure used on grassland and arable land by the effective regional proportions of land use. This was done by calculating a country-specific preference to apply a specific manure type on a certain land use type, i.e. the proportion of manure applied to a certain land use type available on a country basis was divided by the actual proportion of this land use type in the country. This country-specific preference was multiplied with the actual regional land use to obtain a regional estimate of the manure use.

Table S1. Classes and P excretion rates used in calculations of $\mathrm{P}$ loads. $\mathrm{P}$ excretion is given as $\mathrm{kg} \mathrm{P}_{2} \mathrm{O}_{5}$ per year and animal or animal space (if the category has a turnover $>1$ year).

\begin{tabular}{|c|c|c|c|}
\hline Manure categories & Animal classes & $\begin{array}{l}\text { P excretion (1) } \\
{\left[\mathrm{kg} \mathrm{P}_{2} \mathrm{O}_{5} \mathrm{yr}^{-1}\right]}\end{array}$ & Eurostat categories \\
\hline \multirow[t]{7}{*}{ Cattle } & Calves & 7.5 & Total cattle under one year \\
\hline & & & Slaughter calves (<1 year) \\
\hline & & & Other male breeding calves (<1 year) \\
\hline & & & Other female breeding calves ( $<1$ year) \\
\hline & Slaughter cattle & 11 & Male cattle (1-2 years) \\
\hline & & & Female slaughter heifers (1-2 years) \\
\hline & & & Male cattle (2 years and above) \\
\hline \multirow{2}{*}{$\begin{array}{l}\text { Dairy cows and } \\
\text { other cows }\end{array}$} & Dairy cows & 39 & Dairy cows \\
\hline & Other cows & 30 & Other cows \\
\hline \multirow[t]{5}{*}{ Swine } & Pigs $>20 \mathrm{~kg}$ & 6 & Fattening pigs from $20 \mathrm{~kg}$ to under $50 \mathrm{~kg}$ \\
\hline & & & Fattening pigs from $50 \mathrm{~kg}$ and above \\
\hline & Boars and sows & 19 & Breeding boars \\
\hline & & & Total breeding sows \\
\hline & & & Maiden gilts not yet farrowed \\
\hline \multirow{5}{*}{$\begin{array}{l}\text { Sheep goats } \\
\text { and heifers }\end{array}$} & Sheep and goat & 5.3 & Sheep (total) \\
\hline & & & Goats (total) \\
\hline & Heifers & 13 & Breeding heifers (1-2 years) \\
\hline & & & Breeding heifers (2 years and above) \\
\hline & & & Other female cattle (2 years and above) \\
\hline \multirow[t]{2}{*}{ Poultry } & Laying hens & 0.46 & Poultry (total) \\
\hline & Broilers & 0.15 & \\
\hline
\end{tabular}


Table S2. Land use types aggregated from classes of Corine landcover database, Swiss landuse statistics and Pelcom map (for Norway).

\begin{tabular}{|c|c|c|c|}
\hline Landuse type & CORINE land cover $^{1}$ & Swiss landuse statistics $^{2}$ & Pelcom $^{3}$ \\
\hline Arable land & $\begin{array}{l}\text { Non-irrigated arable land } \\
\text { Permanently irrigated land } \\
\text { Rice fields }\end{array}$ & Favourable meadows and arable land & Arable \\
\hline Grassland & Pastures & $\begin{array}{l}\text { Other meadows and arable land } \\
\text { Pasture } \\
\text { Pasture with bushes }\end{array}$ & $\begin{array}{l}\text { Grassland } \\
\text { when annual mean } \\
\text { temp. }>1^{\circ} \mathrm{C} \text { and slope } \\
<10 \%\end{array}$ \\
\hline Mixed areas & $\begin{array}{l}\text { Annual crops associated with } \\
\text { permanent crops } \\
\text { Complex cultivation patterns } \\
\text { Land principally occupied by } \\
\text { agriculture, with significant areas } \\
\text { of natural vegetation }\end{array}$ & Meadows with fruit trees & \\
\hline $\begin{array}{l}\text { Marginal } \\
\text { areas }\end{array}$ & $\begin{array}{l}\text { Natural grasslands } \\
\text { Moors and heathland } \\
\text { Sparsely vegetated areas }\end{array}$ & $\begin{array}{l}\text { Mountain meadows } \\
\text { Mountain pastures with bushes } \\
\text { Favourable alpine pastures } \\
\text { Stony alpine pasture } \\
\text { Other alpine pasture }\end{array}$ & $\begin{array}{l}\text { Grassland } \\
\text { when annual mean } \\
\text { temp. }<1^{\circ} \mathrm{C} \text { and slope } \\
>10 \%\end{array}$ \\
\hline
\end{tabular}

\footnotetext{
${ }^{1}$ European Environment Agency, Copenhagen

2 Federal Statistical Office, Berne

3 DLO-Winand Staring Centre for Integrated Land, Soil and Water Research, Wageningen
} 


\section{SI-3: Sources, transformations and interpretation of environmental variable data}

Environmental data originated from various sources (Table S3). Criteria to be included were: (i) the availability for all of Europe and on a continuous scale for the statistical analyses and (ii) a known monotonic relationship with contamination potential by the three processes runoff, erosion and leaching. The direction of this relationship may not be the same for all three processes. It is shown in Table 1 and explained in detail below.

Estimates of OC content in soil derived from information on soil type, vegetation cover, land use and temperature were available from Jones et al. (5). OC content was assumed to diminish SW contamination in general by increasing the adsorption of VMP to soil.

A more complex relationship was assumed for clay and sand contents: Sand and clay contents were assumed to have both a diminishing effect on soil erodibility which is highest in silty soils (6). In contrast, sand was assumed to increase soil permeability and, thus, leaching; clay was assumed to decrease it. There may certainly be effects on runoff as well, but because soil effects on runoff were summarized by the base-flow index (described below) in a more integrative way, no relationship was included. Information on clay and sand contents were available for Europe only in the form of five classes in the Soil Geographic Database of Europe (SGDBE). We therefore followed an approach used for the FAO Soil Map of the world (7). In a first step, the texture classes present in SGDBE (8) were harmonised with the profile database of the ISRIC World Inventory of Soil Emission Potentials (9). SGDBE texture classes 2 and 3 (medium \& medium fine) were reclassified into one class (medium) and SGDBE classes 4 and 5 (fine \& very fine) were reclassified into one class (fine). In the second step, contents of clay and sand were extracted from the profile database (9) for each harmonised texture class combined with the FAO 74 soil type.

Percentage grassland was calculated from the combined and reclassified land use map (Table S2). It was assumed that grassland reduced erosion whereas experiments showed that runoff of manure was higher from grassland than from arable land (10).

Mean annual temperature was interpolated from New et al. (11) to the required resolution using tension splines with weight 1 and 4 neighbours (12). We assumed that high temperature decreased SW contamination in general because of faster degradation of the substances.

Precipitation data were either derived from interpolated station data $(\mathrm{k}-\mathrm{m})$ or from climate reanalysis data (n) and interpolated using tension splines. Rainfall sum and intensity were calculated only during the relevant time for manure application when monthly temperature is $>3^{\circ} \mathrm{C}$ and $<25^{\circ} \mathrm{C}$. This temperature constraints were suggested by survey data on manure application (13-16). Only the two most relevant 
precipitation variables for each process were accounted for in order to avoid too much weight of precipitation in the selection of scenarios.

Slope was derived from the GTOPO 30 digital elevation model (U.S. Geological Survey: Sioux Falls, USA). It was assumed that runoff and erosion would be high in steep areas, whereas leaching prevailed in flat regions. The distance to rivers was estimated by calculating the shortest Euclidean distance to both, the calculated pan-European river network (17) and digitized maps of streams, lakes and ponds (ESRI Data \& Map, Redlands, USA). It was assumed that a larger distance to rivers would decrease runoff and erosion, but not leaching.

The base-flow index (BFI) describes the share of direct surface runoff and baseflow on total catchment discharge and is determined by soil properties, topography and climate (18). The soil contribution to BFI was represented on a pan-European scale by reclassifying the SGDBE into conceptual classes of water flow through soil according to Boorman et al. (19). Boorman et al. (19) used discharge data from 600 British catchments to estimate a BFI coefficient to each soil class. These estimates were linked to the classes of the reclassified SGDBE to obtain a European map of BFI, which was validated using river discharge data (20).

Information on the presence of shallow groundwater was derived using hydrogeological classes in the SGDBE and a positive relationship to leaching was assumed. 
Table S3. Variables used for the cluster analysis and the subsequent selection of scenarios for environmental risk assessment of veterinary pharmaceuticals. Table includes data sources, data format and transformations used in this study.

\begin{tabular}{|c|c|c|c|c|c|}
\hline & Name & Unit & Source & $\begin{array}{l}\text { Original resolution / } \\
\text { grid size }\end{array}$ & $\begin{array}{l}\text { Transformations } \\
\text { (see text for details) }\end{array}$ \\
\hline & \multicolumn{5}{|c|}{ Load variables } \\
\hline $\mathrm{a}$ & $\begin{array}{l}\text { Manure load dairy and } \\
\text { other cows }\end{array}$ & $\mathrm{kg} \mathrm{P} \mathrm{km}^{-2}$ & $\begin{array}{l}\text { Eurostat and } \\
\text { national statistics }\end{array}$ & $\begin{array}{l}\text { Nuts } 2 \text { regions, } \\
\text { national admin. units }\end{array}$ & $\begin{array}{l}\text { Disaggregation using manure } \\
\text { management and landuse data }\end{array}$ \\
\hline b & $\begin{array}{l}\text { Manure load other } \\
\text { cattle }\end{array}$ & $\mathrm{kg} \mathrm{P} \mathrm{km}{ }^{-2}$ & $\begin{array}{l}\text { Eurostat and } \\
\text { national statistics }\end{array}$ & $\begin{array}{l}\text { Nuts } 2 \text { regions, } \\
\text { national admin. units }\end{array}$ & $\begin{array}{l}\text { Disaggregation using manure } \\
\text { management and landuse data }\end{array}$ \\
\hline C & Manure load swine & $\mathrm{kg} \mathrm{P} \mathrm{km}{ }^{-2}$ & $\begin{array}{l}\text { Eurostat and } \\
\text { national statistics }\end{array}$ & $\begin{array}{l}\text { Nuts } 2 \text { regions, } \\
\text { national admin. units }\end{array}$ & $\begin{array}{l}\text { Disaggregation using manure } \\
\text { management and landuse data }\end{array}$ \\
\hline d & Manure load poultry & $\mathrm{kg} \mathrm{P} \mathrm{km}{ }^{-2}$ & $\begin{array}{l}\text { Eurostat and } \\
\text { national statistics }\end{array}$ & $\begin{array}{l}\text { Nuts } 2 \text { regions, } \\
\text { national admin. units }\end{array}$ & $\begin{array}{l}\text { Disaggregation using manure } \\
\text { management and landuse data }\end{array}$ \\
\hline \multirow[t]{2}{*}{ e } & $\begin{array}{l}\text { Manure load sheep, } \\
\text { goats and heifers }\end{array}$ & $\mathrm{kg} P \mathrm{~km}^{-2}$ & $\begin{array}{l}\text { Eurostat and } \\
\text { national statistics }\end{array}$ & $\begin{array}{l}\text { Nuts } 2 \text { regions, } \\
\text { national admin. units }\end{array}$ & $\begin{array}{l}\text { Disaggregation using manure } \\
\text { management and landuse data }\end{array}$ \\
\hline & \multicolumn{5}{|c|}{ Environmental variables } \\
\hline $\mathrm{f}$ & $\begin{array}{l}\text { Organic carbon in } \\
\text { topsoil }\end{array}$ & $\%$ & (5) & $1 \mathrm{~km}$ & Aggregation \\
\hline g & Clay in topsoil & $\%$ & $(8,9)$ & 1:1 Mio & \\
\hline h & Sand in topsoil & $\%$ & $(8,9)$ & 1:1 Mio & \\
\hline $\mathrm{i}$ & $\begin{array}{l}\text { Grassland on total } \\
\text { agricultural land }\end{array}$ & $\%$ & $\begin{array}{l}\text { Corine }^{1}, \text { Swiss } \\
\text { landuse statistics }^{2} \text {, } \\
\text { Pelcom }^{3}\end{array}$ & $\begin{array}{l}100 \mathrm{~m}, 100 \mathrm{~m}, \\
1 \mathrm{~km}\end{array}$ & Aggregation \\
\hline j & Mean temperature & ${ }^{\circ} \mathrm{C}$ & $(11)$ & $10^{\prime}$ & Tension spline interpolation \\
\hline $\mathrm{k}$ & $\begin{array}{l}\text { Precipitation during } \\
\text { vegetation period }\end{array}$ & $\mathrm{mm}$ & (11) & $10^{\prime}$ & $\begin{array}{l}\text { Average monthly precipitation when } \\
\text { monthly temp. }>3^{\circ} \mathrm{C} \text { and }<25^{\circ} \mathrm{C} \text {; } \\
\text { tension spline interpolation }\end{array}$ \\
\hline 1 & $\begin{array}{l}\text { Precipitation intensity } \\
\text { during VP }\end{array}$ & $\mathrm{mm} \mathrm{d}^{-1}$ & (11) & $10^{\prime}$ & $\begin{array}{l}\text { Average monthly precipitation / } \\
\text { monthly number of days }>0.1 \mathrm{~mm} \\
\text { precip. when monthly temp. }>3^{\circ} \mathrm{C} \text { and } \\
<25^{\circ} \mathrm{C} \text {; tension spline interpolation }\end{array}$ \\
\hline $\mathrm{m}$ & $\begin{array}{l}\text { Extreme rainfall (days } \\
>10 \mathrm{~mm} \text { rain) }\end{array}$ & $\mathrm{d}_{\mathrm{yr}}{ }^{-1}$ & $\begin{array}{l}\text { Hadley regional } \\
\text { climate model } 3^{4} \\
(1960-1990)\end{array}$ & $50 \mathrm{~km}$ & Tension spline interpolation \\
\hline $\mathrm{n}$ & $\begin{array}{l}\text { Duration of longest } \\
\text { dry spell }\end{array}$ & d & $\begin{array}{l}\text { Hadley RCM3 } \\
(1960-1990)\end{array}$ & $50 \mathrm{~km}$ & Tension spline interpolation \\
\hline 0 & Slope & $\%$ & $\mathrm{GTOPO}^{5}{ }^{5}$ & $1 \mathrm{~km}$ & Average maximum technique (21) \\
\hline $\mathrm{p}$ & $\begin{array}{l}\text { Distance to natural } \\
\text { water }\end{array}$ & $\mathrm{m}$ & $\mathrm{CCM}^{6}, \mathrm{ESRI}^{7}$ & $\mathrm{n} / \mathrm{a}$ & Euclidean distance \\
\hline q & Base-flow index & . & $(8,19)$ & 1:1 Mio & $\begin{array}{l}\text { Reclassification into HOST classes } \\
\text { (Table S3) and prediction using BFI } \\
\text { estimates per class from (8) }\end{array}$ \\
\hline $\mathrm{r}$ & Shallow ground water & $\%$ & (8) & $1 \mathrm{~km}$ & $\begin{array}{l}\text { Percentage coverage of HG class } 2 \\
\text { (Soils influenced by groundwater) }\end{array}$ \\
\hline & $\begin{array}{l}{ }^{1} \text { European Environment } \\
2 \\
\text { Federal Statistical Office } \\
{ }^{3} \text { DLO-Winand Staring C } \\
4{ }^{4} \text { http://www.cru.uea.ac.ul } \\
{ }^{5} \text { USGS National Center f } \\
{ }^{6} \text { CCM River and Catchm } \\
7{ }^{7} \text { Major Water and Water }\end{array}$ & $\begin{array}{l}\text { Agency; Cor } \\
\text { e; Berne } \\
\text { entre for Inte } \\
\text { k/projects/m } \\
\text { or Earth Res } \\
\text { ent Databas } \\
\text { Bodies from }\end{array}$ & $\begin{array}{l}\text { enhagen } \\
\text { icrated Land, Soil an } \\
\text { ice/ } \\
\text { ources Observation \& } \\
\text { for Europe, Version } \\
\text { ESRI Maps \& Data, }\end{array}$ & $\begin{array}{l}\text { d Water Research; Wage } \\
\& \text { Science: Sioux Falls } \\
1.0 \\
\text { ESRI: Redlands }\end{array}$ & ningen \\
\hline
\end{tabular}




\section{SI-4: Robustness of partitioning}

The pre-processing of variables was a crucial step in cluster analysis and a number of choices needed to be made here. We therefore assessed the robustness of the partitioning by comparing the partition which was used to select scenarios, with partitions obtained by using: (i) all PC (partition 2) or only the first four (partition 3), (ii) the original environmental variables instead of the principle components (partition 4), (iii) an alternative clustering algorithm (partition 5) or (iv) a larger number of groups (partition 6).

In order to calculate partition 4 , the original variables were standardized by scaling them so that $95 \%$ of the values laid between 0 and 1, a procedure recommended for non-normal data (22).

By calculating partition 5, we evaluated the effect of a second algorithm able to handle large datasets, the $k$-means algorithm (23). K-means first selects a series of centroids at random and assigns all cells to the closest centroid (i.e. where the Euclidean distance is smallest). New centroid values are then calculated using the mean values of all cells in each cluster and all cells are assigned to these new centroids. This step is iterated until no cells change their cluster assignments. In all other calculations, we used an algorithm called clara (24). Clara performs partitioning around medoids, i.e. a set of $k$ representative objects (the medoids) are sought which minimize the sum of dissimilarities of the observations to their closest medoid. Clara was developed for large applications (24): subsets of the data are evaluated iteratively and the medoids with the smallest sum of dissimilarity are retained. The algorithm was modified to stop when, for 2000 iterations, the sum of dissimilarity did not decrease. Because of the calculation of arithmetic means, clara (24) is more robust to outliers than $k$ means.

Both algorithms require the selection of a fixed number of clusters to be obtained. A number of 40 clusters was chosen as a good compromise between only a few, but too general clusters, and many, but too small and spatially incoherent clusters. The effect of forming more groups was assessed using partition 6 .

Two partitions were compared by computing the statistics of Jaccard (25) $I_{J}$ and of Fowlkes and Mallows (26) $I_{F M}$ :

$$
\begin{aligned}
& I_{J}=\frac{N_{i j}}{N_{i j}+N_{i .}+N_{. j}} \\
& I_{F M}=\frac{N_{i j}}{\sqrt{\left(N_{i j}+N_{i .}\right)\left(N_{i j}+N_{. j}\right)}}
\end{aligned}
$$

where $N_{i j}$ is the number of cell pairs present in the same cluster in partitions $i$ and $j, N_{i .}$ and $N_{. j}$ are the number of pairs in the same cluster in partition $i$, but not in partition $j$ and vice versa. Both indexes are 1 if 
the assignment of cells to clusters is identical for two partitions and 0 if the partitions are completely different.

Table S4 shows similarity indexes between partitions, which are displayed in Figure S1, a-f. Similarity indexes were lowest between partitions based on different numbers of PC (Table 2, partitions 1-3). Less difference was found between partition 4 based on the original variables in standardized form and partition 2 based on all PC, as compared to partition 1 and 3. Highest similarities were found between analyses which only differed in the algorithm used (partitions 1 and 6) or where the number of clusters was different (partitions 1 and 5). All partitions evaluated were clearly different from a random attribution of cells to clusters (partition 7). Thus, the number and type of variables included in the cluster analysis had the strongest effects on the results, whereas the algorithm and the number of clusters had less impact.

Table S4. Similarity between partitions obtained in cluster analyses with different preparatory steps. $\mathrm{I}_{\mathrm{FM}}$ and $\mathrm{I}_{\mathrm{J}}$ are similarity indexes by Jaccard $\mathrm{I}_{\mathrm{J}}(25)$ and Fowlkes and Mallows $\mathrm{I}_{\mathrm{FM}}(26)$.

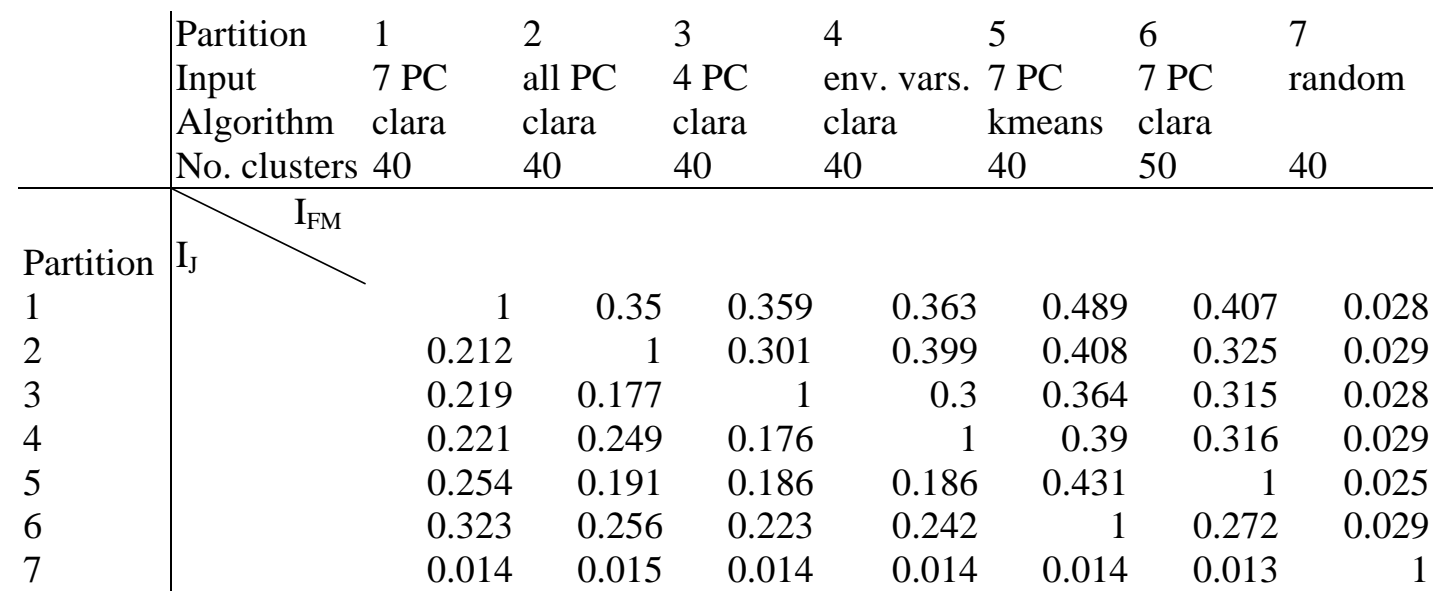


Figure S1, a-f. Partitions obtained after different preparatory steps varying number and type of variables, algorithm and the number of clusters: (a) 7 PC, 40 clusters, clara; (b) all PC, 40 clusters, clara; (c) 4 PC, 40 clusters, clara; (d) standardized variables, 40 clusters, clara; (e) 7 PC, 40 clusters, k means; (f) 7 PC, 50 clusters, clara.
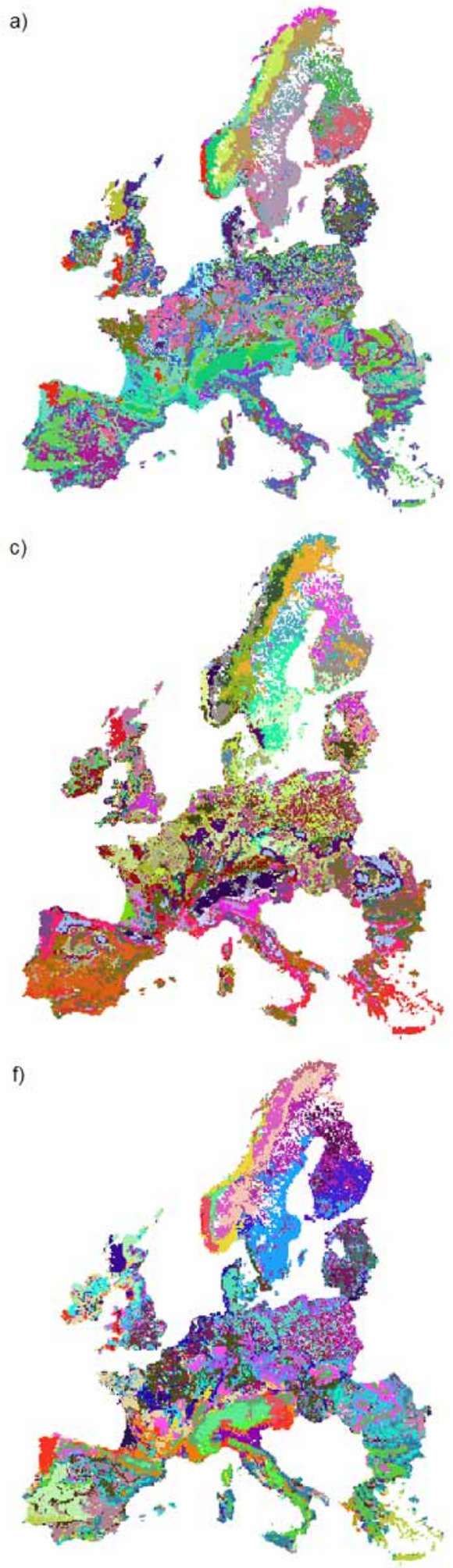
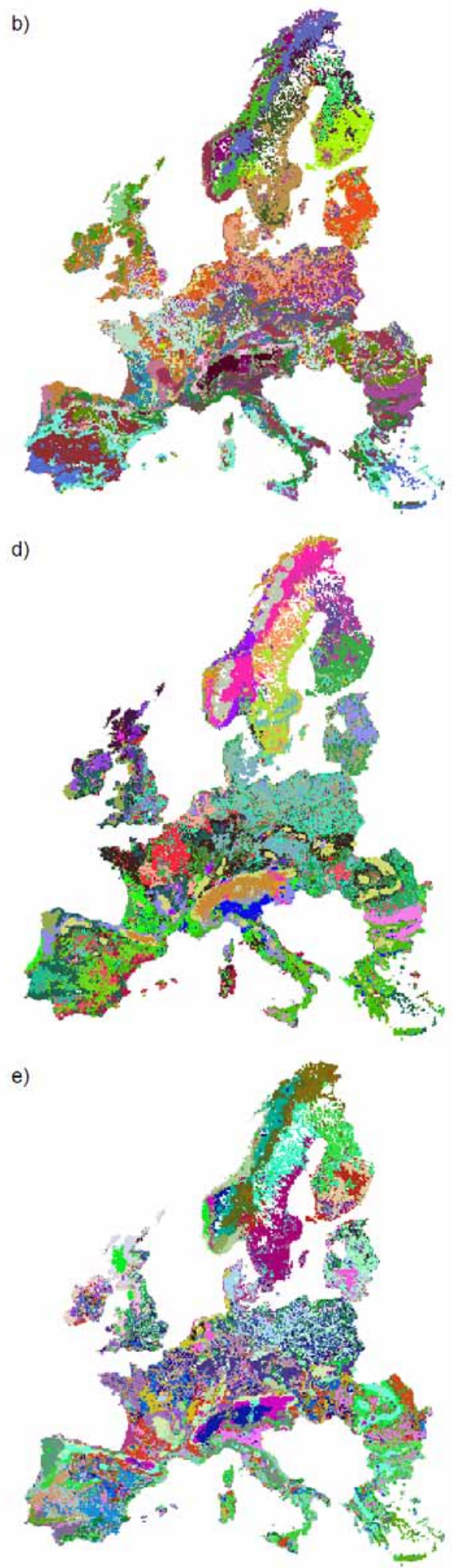


\section{SI-5: Detailed results of PCA}

Table S5. Results of principal component analysis on environmental variables. Principal components are shown with the loadings of environmental variables and the proportion of explained variance.

\begin{tabular}{llrrrrrrr}
\hline & PC 1 & PC 2 & PC 3 & PC 4 & PC 5 & PC 6 & PC 7 \\
\hline Loadings & -0.191 & -0.297 & $\mathbf{0 . 3 9 1}$ & -0.166 & 0.04 & -0.293 & $\mathbf{- 0 . 4 1 5}$ \\
& \% organic C & 0.25 & 0.207 & $\mathbf{0 . 4 1 4}$ & -0.285 & 0.023 & -0.176 & 0.287 \\
& \% clay & -0.207 & -0.242 & $\mathbf{- 0 . 4 2 2}$ & 0.329 & -0.127 & 0.222 & -0.21 \\
\% sand & $\mathbf{- 0 . 4 0 5}$ & 0.103 & 0.028 & -0.196 & -0.089 & 0.14 & -0.278 \\
\% grassland & $\mathbf{0 . 3 5 4}$ & $\mathbf{0 . 4 0 4}$ & -0.102 & 0.065 & -0.069 & 0.019 & -0.246 \\
Mean temperature & -0.107 & $\mathbf{0 . 4 2}$ & 0.171 & $\mathbf{0 . 4 3 8}$ & 0.126 & -0.275 & $\mathbf{- 0 . 4 0 3}$ \\
Precipitation sum & -0.184 & $\mathbf{0 . 4 7 4}$ & 0.013 & 0.125 & 0.066 & -0.035 & -0.028 \\
Precipitation intensity & $\mathbf{- . 4 2 5}$ & 0.209 & 0.062 & 0.162 & 0.192 & -0.034 & 0.314 \\
Extreme rainfall & 0.314 & 0.306 & -0.203 & -0.303 & -0.167 & 0.307 & -0.275 \\
Duration of dry spell & $\mathbf{- . 3 6 1}$ & 0.293 & -0.103 & -0.211 & 0.014 & 0.292 & 0.333 \\
Slope & 0.247 & -0.103 & 0.069 & 0.195 & $\mathbf{0 . 8 1 1}$ & $\mathbf{0 . 3 6 9}$ & -0.023 \\
Distance to water & 0.14 & 0.023 & $\mathbf{- 0 . 5 3}$ & 0.082 & 0.091 & $\mathbf{- 0 . 6 1 5}$ & 0.224 \\
Base-flow index & 0.182 & -0.037 & 0.34 & $\mathbf{0 . 5 7 1}$ & $\mathbf{- 0 . 4 6 6}$ & 0.205 & 0.254 \\
Shallow ground water & & & & & & & \\
& 25.0 & 19.8 & 12.0 & 7.85 & 6.62 & 6.15 & 5.63 \\
\% explained variance & 25.0 & 44.8 & 56.7 & 64.6 & 71.2 & 77.4 & 83.0 \\
\hline
\end{tabular}




\section{SI-6: Median variable values for selected and existing FOCUS and VetCalc scenarios}

Table S6. Median variable values for scenarios selected from the clustering of the first seven principal components of environmental variables. The values extracted from matrix of variables in Table S3, the size in $\mathrm{km}^{2}$, the average risk score for runoff, erosion or leaching and the relevance of these three processes are shown. The geographic coverage of the selected clusters is shown in Figure 2 (main text).

\begin{tabular}{|c|c|c|c|c|c|c|c|c|c|c|c|c|c|c|c|c|c|c|}
\hline & 1 & 2 & 3 & 4 & 5 & 6 & 7 & 8 & 9 & 10 & 11 & 12 & 13 & 14 & 15 & 16 & 17 & 18 \\
\hline $\mathrm{a}$ & 126 & 150 & 111 & 80.1 & 117 & 83 & 88.9 & 30.4 & 60.5 & 67.2 & 56.4 & 31.3 & 31.4 & 33.1 & 58.1 & 57.4 & 64.2 & 62.8 \\
\hline b & 25.7 & 36.8 & 19.3 & 15.7 & 25.1 & 16.1 & 21.4 & 6.95 & 12.1 & 16.6 & 12.7 & 6.5 & 7.11 & 7.98 & 12.1 & 10.7 & 11.8 & 11.5 \\
\hline C & 43 & 35 & 18.4 & 20.3 & 49.4 & 12.5 & 23.9 & 26.1 & 39.4 & 42.6 & 50.2 & 43.9 & 30.7 & 10.9 & 47.7 & 35.1 & 49.7 & 52.3 \\
\hline$d$ & 0.204 & 0.103 & 0.0621 & 0.0841 & 0.139 & 0.0151 & 0.0422 & 0.143 & 0.152 & 0.0904 & 0.149 & 0.16 & 0.134 & 0.0238 & 0.143 & 0.0804 & 0.214 & 0.19 \\
\hline e & 23.3 & 31 & 31.1 & 38.9 & 19.1 & 23.8 & 18.9 & 39.1 & 23.7 & 12.8 & 17.6 & 34 & 40.4 & 17.2 & 4.35 & 7.43 & 4.21 & 4.04 \\
\hline $\mathrm{f}$ & 1.76 & 3.06 & 6.43 & 1.94 & 3.88 & 4.73 & 6.03 & 1.34 & 2.39 & 3.18 & 3.04 & 2.13 & 1.95 & 3.27 & 4.75 & 5.13 & 4.94 & 4.94 \\
\hline g & 16.2 & 14.5 & 14.1 & 16.7 & 13.9 & 9.73 & 14.6 & 17.4 & 16.4 & 15.1 & 25.4 & 34.7 & 22.5 & 15 & 9.73 & 5.94 & 15.7 & 7.96 \\
\hline h & 32.3 & 33.5 & 31.5 & 31.2 & 36.3 & 41.9 & 30 & 30.1 & 31.2 & 30.6 & 23.7 & 17.4 & 25.5 & 32.1 & 38.3 & 44.9 & 32.1 & 41.6 \\
\hline $\mathrm{i}$ & 23.6 & 45.1 & 95 & 44.8 & 26.8 & 86.9 & 66.7 & 17.7 & 16.2 & 14.9 & 12.8 & 17.9 & 24.4 & 78.2 & 20.3 & 28.7 & 21.5 & 19.5 \\
\hline $\mathrm{j}$ & 12.3 & 9.8 & 8.87 & 12.3 & 9.2 & 8.24 & 7.94 & 14.2 & 9.99 & 9.23 & 9.81 & 11.3 & 11.3 & 11 & 7.77 & 8.2 & 8.08 & 8.24 \\
\hline $\mathrm{k}$ & 750 & 719 & 1090 & 819 & 630 & 728 & 639 & 504 & 579 & 560 & 519 & 486 & 471 & 921 & 438 & 478 & 450 & 445 \\
\hline l & 5.74 & 4.64 & 6.17 & 6.02 & 4.26 & 5.5 & 4.9 & 5.29 & 4.54 & 4.34 & 4.4 & 4.89 & 4.8 & 7.14 & 4.18 & 4.27 & 4.23 & 4.11 \\
\hline $\mathrm{m}$ & 14.8 & 16 & 32.7 & 18.1 & 13.7 & 28.2 & 27.2 & 8.64 & 12.6 & 15 & 12.6 & 10.5 & 10.3 & 30.7 & 12 & 12.5 & 11.5 & 12 \\
\hline $\mathrm{n}$ & 17.4 & 14.9 & 13.2 & 16.8 & 14.2 & 13.6 & 13.2 & 25.2 & 16 & 14.3 & 15 & 22.2 & 22.8 & 17.9 & 13.9 & 14 & 14 & 13.6 \\
\hline 0 & 0.638 & 1.53 & 3.48 & 2.21 & 0.534 & 3.97 & 2.88 & 1.65 & 0.931 & 1.4 & 1.02 & 1.12 & 2.16 & 7.9 & 0.592 & 0.437 & 0.477 & 0.481 \\
\hline $\mathrm{p}$ & 1110 & 1430 & 1130 & 1200 & 1210 & 973 & 1350 & 1140 & 3510 & 1650 & 1670 & 1450 & 1670 & 934 & 1540 & 1190 & 2690 & 3070 \\
\hline$q$ & 0.704 & 0.623 & 0.55 & 0.801 & 0.692 & 0.613 & 0.596 & 0.602 & 0.634 & 0.737 & 0.677 & 0.663 & 0.619 & 0.733 & 0.677 & 0.797 & 0.507 & 0.72 \\
\hline r & 82.2 & 1.4 & 0 & 1.11 & 57.2 & 0 & 0 & 45.6 & 0 & 0 & 20.3 & 0 & 0 & 0 & 0 & 6.18 & 36 & 0.73 \\
\hline size & 8930 & 21760 & 9910 & 17750 & 14440 & 15180 & 16060 & 9950 & 11940 & 26290 & 10760 & 11690 & 14160 & 11060 & 13630 & 16700 & 8180 & 11460 \\
\hline $\mathrm{Tm}$ & 3.82 & 3.77 & 3.34 & 3.35 & 3.7 & 2.83 & 3.17 & 3.06 & 3.38 & 3.26 & 3.37 & 3.17 & 3.1 & 2.35 & 3.1 & 2.92 & 3.21 & 3.18 \\
\hline $\operatorname{Tr}$ & 4.77 & 4.71 & 5.78 & 5.03 & 3.84 & 5.64 & 4.89 & 4.92 & 3.85 & 3.65 & 3.66 & 4.25 & 4.48 & 5.99 & 3.25 & 3.29 & 3.45 & 2.69 \\
\hline $\mathrm{Te}$ & 5.48 & 5.01 & 5.35 & 5.68 & 4.58 & 5.54 & 5.27 & 5.51 & 4.71 & 5.08 & 4.87 & 5.21 & 5.22 & 6.18 & 4.51 & 4.64 & 4.03 & 4.07 \\
\hline $\mathrm{Tl}$ & 5.08 & 4.41 & 4.4 & 4.4 & 4.8 & 4.89 & 3.91 & 4.12 & 4.07 & 3.86 & 3.43 & 3.22 & 3.21 & 4.27 & 4.38 & 4.95 & 4.09 & 4.54 \\
\hline $\mathrm{Rr}$ & 18.2 & 17.8 & 19.3 & 16.9 & 14.2 & 15.9 & 15.5 & 15.1 & 13 & 11.9 & 12.3 & 13.5 & 13.9 & 14.1 & 10.1 & 9.62 & 11.1 & 8.56 \\
\hline $\mathrm{Re}$ & 21 & 18.9 & 17.9 & 19 & 17 & 15.7 & 16.7 & 16.8 & 15.9 & 16.5 & 16.4 & 16.5 & 16.2 & 14.5 & 14 & 13.5 & 12.9 & 13 \\
\hline $\mathrm{Rl}$ & 19.4 & 16.6 & 14.7 & 14.8 & 17.8 & 13.8 & 12.4 & 12.6 & 13.8 & 12.6 & 11.5 & 10.2 & 9.97 & 10 & 13.6 & 14.5 & 13.1 & 14.5 \\
\hline runoff & + & + & + & + & + & + & + & + & & & & + & + & + & & & & \\
\hline erosion & + & + & + & + & + & & + & + & + & + & + & + & + & & & & & \\
\hline leaching & + & + & + & + & + & + & & & + & & & & & & + & + & + & + \\
\hline
\end{tabular}


Table S7. Median variable values for existing scenarios of Focus and VetCalc. Values extracted from

matrix of variables in Table S3 at locations where scenario coverage is given by the authors $(27,28)$.

\begin{tabular}{|c|c|c|c|c|c|c|c|c|c|c|c|c|c|c|c|c|c|c|c|c|c|c|}
\hline & 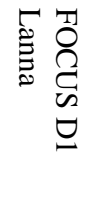 & 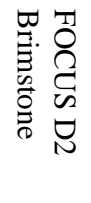 & 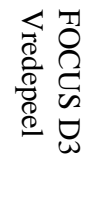 & 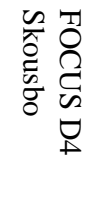 & 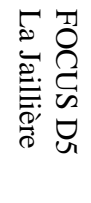 & 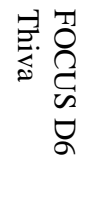 & 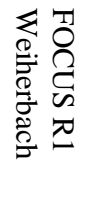 & 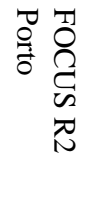 & 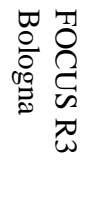 & 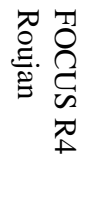 & 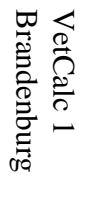 & 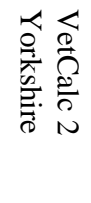 & 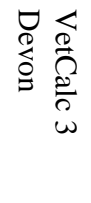 & 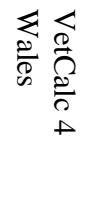 & 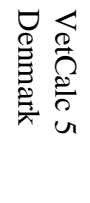 & 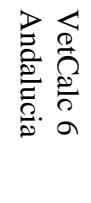 & 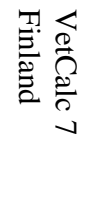 & 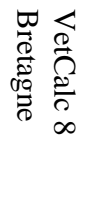 & 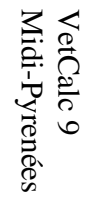 & 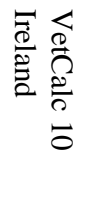 & 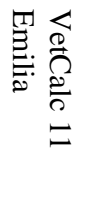 & 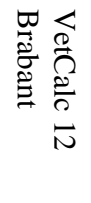 \\
\hline $\mathrm{a}$ & 16.5 & 125 & 194 & 121 & 112 & 31.2 & 95.3 & 40.6 & 72.2 & 17.4 & 76.8 & 95 & 276 & 185 & 150 & 16.9 & 13.2 & 290 & 113 & 251 & 131 & 411 \\
\hline b & 4.2 & 35.9 & 50 & 27.9 & 21.9 & 7.14 & 20.9 & 8.46 & 14.2 & 4.75 & 13.1 & 30.7 & 71.7 & 51.2 & 24.4 & 2.27 & 3.05 & 54 & 18.9 & 107 & 20 & 106 \\
\hline C & 9.01 & 31.2 & 393 & 41.6 & 21.6 & 20.5 & 54.7 & 9.79 & 20.5 & 25 & 33.3 & 140 & 32.9 & 4.15 & 397 & 26.5 & 15.5 & 383 & 15.9 & 35.8 & 102 & 1130 \\
\hline d & 0.0159 & 0.393 & 0.216 & 0.139 & 0.0829 & 0.0762 & 0.0869 & 0.0308 & 0.0819 & 0.0463 & 0.104 & 0.343 & 0.407 & 0.257 & 0.097 & 0.024 & 0.0197 & 0.846 & 0.0469 & 0.0581 & 0.332 & 3.49 \\
\hline e & 1.24 & 40.8 & 18.2 & 21.9 & 32.2 & 47.2 & 14.2 & 32.5 & 34.2 & 48.4 & 9.69 & 108 & 168 & 405 & 9.24 & 40.7 & 1.25 & 24.8 & 70.4 & 98.3 & 12.3 & 42.4 \\
\hline t & 9.9 & 3.04 & 6 & 4.13 & 2.17 & 1.15 & 3.84 & 1.94 & 2.05 & 1.11 & 5.82 & 5.57 & 4.41 & 9.24 & 4.1 & 1.07 & 8.87 & 2.27 & 2.09 & 7.36 & 1.54 & 6.03 \\
\hline g & 12 & 26.7 & 4.78 & 14.2 & 16 & 15.8 & 14.9 & 13.9 & 15 & 15.7 & 6.53 & 13.6 & 13.7 & 15.3 & 6.59 & 18.2 & 12 & 14.8 & 18.2 & 15.2 & 14.9 & 2.61 \\
\hline h & 49.1 & 27.2 & 43.9 & 32 & 32.7 & 31.6 & 30.3 & 34.9 & 34.1 & 33.4 & 41.6 & 29.2 & 29.6 & 30.8 & 43.9 & 30.1 & 56.2 & 34.9 & 30.7 & 30.8 & 31.4 & 46.6 \\
\hline 1 & 33.6 & 36 & 24.1 & 32.9 & 38.5 & 30.2 & 17.2 & 69.4 & 50.4 & 44.9 & 21.5 & 40.2 & 86.2 & 97.3 & 10.9 & 53.4 & 32 & 37.6 & 52.2 & 85.4 & 37.2 & 24.7 \\
\hline J & 3.41 & 9.52 & 8.94 & 8.88 & 11.2 & 14.8 & 8.48 & 13.2 & 12.1 & 15 & 8.91 & 8.41 & 10 & 8.71 & 7.74 & 15.9 & 3.82 & 11.2 & 11.8 & 9.16 & 12.5 & 9.69 \\
\hline k & 361 & 676 & 596 & 634 & 717 & 575 & 564 & 931 & 774 & 548 & 448 & 682 & 970 & 971 & 491 & 547 & 368 & 776 & 844 & 918 & 726 & 656 \\
\hline 1 & 4.1 & 4.26 & 4.23 & 4.21 & 4.42 & 5.46 & 4.29 & 6 & 5.48 & 4.72 & 3.7 & 3.93 & 4.99 & 5.25 & 4.4 & 4.71 & 4.13 & 4.23 & 6.03 & 4.24 & 6.81 & 4.19 \\
\hline $\mathrm{m}$ & 10.3 & 12.6 & 12.7 & 14.9 & 14.7 & 9.9 & 15.2 & 22.4 & 15.2 & 8.64 & 12.4 & 11.8 & 23.9 & 29.6 & 12.2 & 7.66 & 9.72 & 14.2 & 25.4 & 21.5 & 14.3 & 13.7 \\
\hline$n$ & 11.7 & 14 & 14 & 13.7 & 16.3 & 25.6 & 13.7 & 22.6 & 18.1 & 31.4 & 13.1 & 13.4 & 14.7 & 13.3 & 14.5 & 35.7 & 12 & 16.8 & 15.6 & 12.1 & 22.5 & 13.8 \\
\hline 0 & 0.594 & 0.787 & 0.244 & 0.972 & 0.966 & 1.86 & 1.44 & 4.69 & 2.26 & 2.37 & 0.378 & 1.66 & 1.51 & 2.5 & 0.523 & 4.03 & 0.543 & 1.03 & 2.23 & 1.37 & 1.65 & 0.0789 \\
\hline p & 1220 & 1830 & 1430 & 1500 & 1200 & 1250 & 1600 & 1180 & 1280 & 1490 & 1550 & 1480 & 1650 & 1400 & 894 & 1320 & 1110 & 1480 & 1190 & 1300 & 1260 & 1490 \\
\hline$q$ & 0.703 & 0.496 & 0.828 & 0.629 & 0.689 & 0.644 & 0.691 & 0.612 & 0.647 & 0.656 & 0.732 & 0.436 & 0.537 & 0.519 & 0.739 & 0.681 & 0.747 & 0.594 & 0.725 & 0.72 & 0.607 & 0.935 \\
\hline$\underline{r}$ & 0 & 40.7 & 21 & 12.6 & 14.5 & 16.9 & 0 & 0 & 0 & 0 & 10.1 & 21.5 & 0 & 0 & 0 & 0 & 0 & 0 & 0.105 & 14.6 & 39.4 & 100 \\
\hline size & 16940 & 2650 & 5760 & 40540 & 10080 & 8840 & 18990 & 2700 & 8120 & 31740 & 3060 & 830 & 1070 & 2060 & 4330 & 8700 & 4450 & 2740 & 4580 & 6980 & 2200 & 500 \\
\hline $\mathrm{T}_{\mathrm{m}}$ & 1.53 & 4.04 & 4.19 & 3.72 & 3.47 & 2.92 & 3.48 & 2.6 & 3.26 & 2.61 & 3.14 & 4.4 & 4.48 & 3.93 & 3.73 & 2.33 & 1.58 & 4.48 & 3.42 & 4.07 & 3.9 & 4.74 \\
\hline $\mathrm{T}_{\mathrm{r}}$ & 3.03 & 4.33 & 3.03 & 3.92 & 4.52 & 5.04 & 3.69 & 6.06 & 5.3 & 4.88 & 2.54 & 4.34 & 5.25 & 5.37 & 3.8 & 5.11 & 3.03 & 4.63 & 5.23 & 4.11 & 5.56 & 2.8 \\
\hline $\mathrm{T}_{\mathrm{e}}$ & 3.8 & 4.25 & 4.35 & 4.62 & 4.95 & 5.45 & 5 & 5.94 & 5.4 & 4.96 & 4 & 4.49 & 5.01 & 4.77 & 5.36 & 5.15 & 3.83 & 4.68 & 5.66 & 4.14 & 5.89 & 4.13 \\
\hline $\mathrm{T}_{\mathrm{l}}$ & 4.27 & 3.88 & 5.2 & 4.23 & 4.39 & 4.31 & 3.84 & 4.63 & 4.51 & 3.94 & 4.46 & 3.91 & 4.34 & 4.07 & 5.05 & 3.46 & 4.39 & 4.38 & 4.3 & 4.02 & 4.94 & 5.52 \\
\hline $\mathrm{R}_{\mathrm{r}}$ & 4.65 & 17.5 & 12.7 & 14.6 & 15.7 & 14.7 & 12.8 & 15.7 & 17.3 & 12.7 & 7.96 & 19.1 & 23.5 & 21.1 & 14.2 & 11.9 & 4.78 & 20.8 & 17.9 & 16.7 & 21.7 & 13.3 \\
\hline $\mathrm{R}_{\mathrm{e}}$ & 5.83 & 17.2 & 18.2 & 17.2 & 17.2 & 15.9 & 17.4 & 15.4 & 17.6 & 12.9 & 12.6 & 19.7 & 22.4 & 18.7 & 20 & 12 & 6.05 & 20.9 & 19.4 & 16.8 & 23 & 19.6 \\
\hline $\mathrm{R}_{\mathrm{l}}$ & 6.56 & 15.6 & 21.8 & 15.7 & 15.2 & 12.6 & 13.3 & 12 & 14.7 & 10.3 & 14 & 17.2 & 19.4 & 16 & 18.8 & 8.05 & 6.94 & 19.6 & 14.7 & 16.3 & 19.2 & 26.2 \\
\hline
\end{tabular}


Table S8. Distance values D between existing and selected scenarios. Values of 2 and 3 represent an average difference between the 18 variables of less than $40 \%$ and are highlighted in bold.

\begin{tabular}{|c|c|c|c|c|c|c|c|c|c|c|c|c|c|c|c|c|c|c|c|}
\hline & \multirow[b]{2}{*}{ Existing scenario } & \multicolumn{18}{|c|}{ Selected scenario } \\
\hline & & 1 & 2 & 3 & 4 & 5 & 6 & 7 & 8 & 9 & 10 & 11 & 12 & 13 & 14 & 15 & 16 & 17 & 18 \\
\hline \multirow{10}{*}{$\begin{array}{l}\text { To } \\
\text { 尺े } \\
\text { cे }\end{array}$} & D1 Lanna & 8 & 8 & 8 & 8 & 7 & 7 & 7 & 7 & 8 & 7 & 8 & 7 & 7 & 7 & 6 & 6 & 6 & 6 \\
\hline & D2 Brimstone & 3 & 3 & 6 & 5 & 3 & 6 & 5 & 5 & 4 & 5 & 3 & 5 & 5 & 7 & 5 & 5 & 4 & 6 \\
\hline & D3 Vredepeel & 5 & 5 & 7 & 7 & 4 & 7 & 6 & 7 & 6 & 6 & 5 & 7 & 7 & 8 & 5 & 4 & 5 & 5 \\
\hline & D4 Skousbo & 3 & 2 & 5 & 4 & 2 & 5 & 4 & 5 & 3 & 3 & 3 & 5 & 5 & 6 & 4 & 4 & 4 & 4 \\
\hline & D5 La Jaillière & 3 & 2 & 4 & 2 & 3 & 5 & 4 & 4 & 4 & 4 & 3 & 5 & 4 & 6 & 5 & 4 & 5 & 6 \\
\hline & D6 Thiva & 5 & 5 & 6 & 3 & 5 & 6 & 5 & 2 & 5 & 5 & 4 & 4 & 3 & 5 & 6 & 5 & 6 & 7 \\
\hline & R1 Weiherbach & 4 & 3 & 5 & 4 & 3 & 5 & 4 & 5 & 3 & 2 & 3 & 5 & 5 & 6 & 4 & 4 & 4 & 4 \\
\hline & R2 Porto & 6 & 5 & 4 & 4 & 6 & 4 & 5 & 5 & 6 & 6 & 6 & 6 & 5 & 3 & 7 & 7 & 7 & 8 \\
\hline & R3 Bologna & 4 & 3 & 4 & 2 & 4 & 4 & 4 & 4 & 4 & 4 & 5 & 5 & 4 & 5 & 5 & 5 & 6 & 6 \\
\hline & R4 Roujan & 6 & 5 & 6 & 4 & 6 & 7 & 5 & 3 & 6 & 6 & 6 & 5 & 4 & 6 & 7 & 6 & 7 & 7 \\
\hline \multirow{12}{*}{$\begin{array}{l}\text { व } \\
\frac{0}{0} \\
\stackrel{8}{\Omega}\end{array}$} & 1 Brandenburg & 5 & 5 & 6 & 5 & 3 & 6 & 5 & 5 & 4 & 4 & 3 & 6 & 5 & 7 & 3 & 2 & 3 & 3 \\
\hline & 2 Yorkshire & 5 & 4 & 5 & 5 & 4 & 6 & 5 & 6 & 5 & 5 & 4 & 6 & 6 & 8 & 5 & 5 & 4 & 6 \\
\hline & 3 Devon & 6 & 4 & 5 & 6 & 6 & 6 & 5 & 7 & 6 & 6 & 6 & 7 & 6 & 7 & 7 & 7 & 6 & 7 \\
\hline & 4 Wales & 6 & 5 & 5 & 6 & 6 & 6 & 5 & 8 & 7 & 7 & 7 & 8 & 7 & 7 & 7 & 8 & 7 & 8 \\
\hline & 5 Denmark & 5 & 5 & 7 & 6 & 4 & 6 & 6 & 7 & 6 & 4 & 5 & 7 & 7 & 8 & 4 & 4 & 5 & 5 \\
\hline & 6 Andalucia & 7 & 6 & 7 & 5 & 7 & 6 & 6 & 4 & 6 & 7 & 7 & 6 & 5 & 6 & 8 & 7 & 8 & 8 \\
\hline & 7 Finland & 8 & 8 & 8 & 8 & 7 & 7 & 7 & 7 & 8 & 7 & 8 & 8 & 7 & 7 & 6 & 6 & 6 & 6 \\
\hline & 8 Bretagne & 4 & 4 & 7 & 5 & 5 & 7 & 6 & 6 & 5 & 5 & 6 & 6 & 6 & 7 & 6 & 7 & 6 & 7 \\
\hline & 9 Midi-Pyrenées & 4 & 4 & 3 & 2 & 5 & 4 & 4 & 5 & 5 & 5 & 6 & 6 & 5 & 5 & 7 & 6 & 7 & 7 \\
\hline & 10 Ireland & 5 & 4 & 4 & 5 & 5 & 6 & 4 & 6 & 6 & 5 & 5 & 7 & 7 & 6 & 6 & 6 & 6 & 7 \\
\hline & 11 Emilia & 3 & 4 & 6 & 4 & 3 & 6 & 5 & 4 & 5 & 4 & 4 & 5 & 5 & 6 & 6 & 6 & 5 & 6 \\
\hline & 12 Brabant & 6 & 7 & 8 & 8 & 6 & 8 & 8 & 8 & 8 & 8 & 8 & 8 & 8 & 9 & 7 & 7 & 7 & 8 \\
\hline
\end{tabular}




\section{References for Supporting Information}

(1) Walther, U.; Ryser, J. P.; Flisch, R. Grundlagen für die Düngung im Acker- und Futterbau. Agrarforschung 2001, 8, 1-80.

(2) Burton, C. H.; Turner, C. Manure Management: Treatment Strategies for Sustainable Agriculture; Silsoe Research Institute: Wrest Park, 2003.

(3) Klimont, Z.; Brink, C. Modelling of Emissions of Air Pollutants and Greenhouse Gases from Agricultural Sources in Europe; International Institute for Applied Systems Analysis, Interim Report IR04-48: Laxenburg, 2004.

(4) Schmit, C.; Rousevell, M. D. A.; La Jeunesse, I. The limitations of spatial land use data in environmental analysis. Environmental Science \& Policy 2006, 9, 174-188.

(5) Jones, R. J. A.; Hiederer, R.; Rusco, E.; Montanarella, L. Estimating organic carbon in the soils of Europe for policy support. European Journal of Soil Science 2005, 56, 655-671.

(6) Van der Knijff, J. M.; Jones, R. J. A.; Montanarella, L. Soil Erosion Risk Assessment in Europe; Office for Official Publications of the European Communities, EUR 19022 EN: Luxembourg, 2000.

(7) Reynolds, C. A.; Jackson, T. J.; Rawls, W. J. Estimating soil water-holding capacities by linking the Food and Agriculture Organization soil map of the world with global pedon databases and continuous pedotransfer functions. Water Resources Research 2000, 36, 3653-3662.

(8) ESB European soil database, distribution version v2.0; European Soil Bureau, Joint Research Centre: Ispra, 2003.

(9) Batjes, N. H. A homogenized soil profile dataset for global and regional environmental research (WISE); International soil reference and information centre: Wageningen, 2002.

(10) Burkhardt, M.; Stamm, C.; Waul, C.; Singer, H.; Müller, S. Surface runoff and transport of sulfonamide antibiotics and tracers on manured grassland. Journal of Environmental Quality 2005, 34, 1363-1371.

(11) New, M.; Lister, D.; Hulme, M.; Makin, I. A high-resolution data set of surface climate over global land areas. Climate Research 2002, 21, 1-25.

(12) Schweikert, D. G. An interpolatory curve using a spline in tension. Journal of Mathematics and Physics 1966, 45, 312-317.

(13) Montfors, M. H. M. M. ; Tarazona Lafarga, J. V. Environmental risk assessment for veterinary medical products; RIVM report 601450017/2003: Bilthoven, 2003.

(14) Smith, K. A.; Brewer, A. J.; Crabb, J.; Dauven, A. A survey of the production and use of animal manures in England and Wales. III. Cattle manures. Soil Use and Management 2001, 17, 77-87.

(15) Smith, K. A.; Brewer, A. J.; Crabb, J.; Dauven, A. A survey of the production and use of animal manures in England and Wales. II. Poultry manure. Soil Use and Management 2001, 17, 48-56.

(16) Smith, K. A.; Brewer, A. J.; Dauven, A.; Wilson, D. W. A survey of the production and use of animal 
manures in England and Wales. I. Pig manure. Soil Use and Management 2000, 16, 124-132.

(17) Vogt, J. V.; Colombo, R.; Bertolo, F. Deriving drainage networks and catchment boundaries: a new methodology combining digital elevation data and environmental characteristics. Geomorphology 2003, 53, 281-298.

(18) Soulsby, C.; Tetzlaff, D.; Dunn, S. M.; Waldron, S. Scaling up and out in runoff process understanding: insights from nested experimental catchment studies. Hydrological Processes 2006, 20, 2461-2465.

(19) Boorman, D. B.; Hollis, J. M.; Lilly A. Hydrology of soil types: a hydrologically-based classification of the soils of the United Kingdom; Institute of Hydrology: Wallingford, 1995.

(20) Schneider, M. K.; Brunner, F.; Hollis, J. M.; Stamm, C. Towards a hydrological classification of European soils: Preliminary test of its predictive power for the base flow index using river discharge data. Hydrology and Earth System Sciences Discussions, in press.

(21) Burrough, P. A. Principles of geographical information systems for land resources assessment; Oxford University Press: New York, 1986.

(22) Milligan, G. W.; Cooper, M. C. A study of standardization of variables in cluster analysis. Journal of Classification 1988, 5, 181-204.

(23) Hartigan, J. A.; Wong, M. A. A k-means clustering algorithm. Applied Statistics 1979, 28, 100-108.

(24) Kaufman, L.; Rousseeuw, P. J. Finding groups in data: An introduction to cluster analysis; John Wiley \& Sons: New York, 1990.

(25) Jaccard, P. Distribution de la flore alpine dans le bassin de Dranses et dans quelques régions voisines. Bulletin de la Société Vaudoise des Sciences Naturelles 1901, 37, 241-272.

(26) Fowlkes, E. B.; Mallows, C. L. A method for comparing 2 hierarchical clusterings. Journal of the American Statistical Association 1983, 78, 553-569.

(27) FOCUS Working Group on Surface Waters. FOCUS surface water scenarios in the EU evaluation process under 91/414/EEC; EC document SANCO/4802/2001-rev.2 final: Brussels, 2001.

(28) Mackay, N.; Mason, P.; Di Guardo, A. VetCalc exposure modelling tool for veterinary medicines; Defra Research Project VM02133: London, 2005. 